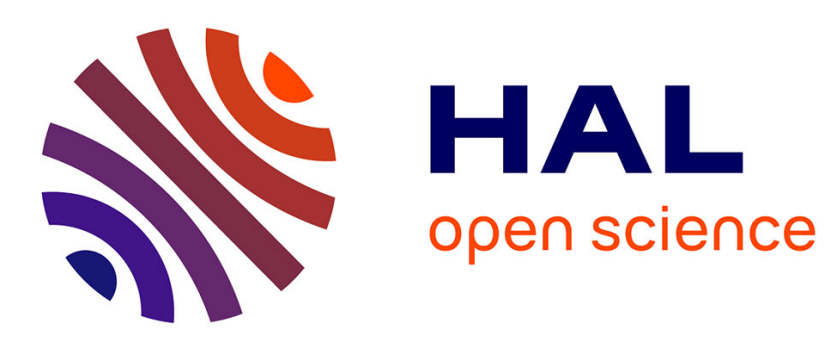

\title{
High environmental risk and low yield of urban tomato gardens in Benin
}

Aurélie Perrin, Claudine Basset-Mens, Joël Huat, Wilfried Yehouessi

\section{To cite this version:}

Aurélie Perrin, Claudine Basset-Mens, Joël Huat, Wilfried Yehouessi. High environmental risk and low yield of urban tomato gardens in Benin. Agronomy for Sustainable Development, 2015, 35 (1), pp.305-315. 10.1007/s13593-014-0241-6 . hal-01284264

\section{HAL Id: hal-01284264 \\ https://hal.science/hal-01284264}

Submitted on 7 Mar 2016

HAL is a multi-disciplinary open access archive for the deposit and dissemination of scientific research documents, whether they are published or not. The documents may come from teaching and research institutions in France or abroad, or from public or private research centers.
L'archive ouverte pluridisciplinaire HAL, est destinée au dépôt et à la diffusion de documents scientifiques de niveau recherche, publiés ou non, émanant des établissements d'enseignement et de recherche français ou étrangers, des laboratoires publics ou privés.

$$
\text { Copyright }
$$




\title{
High environmental risk and low yield of urban tomato gardens in Benin
}

\author{
Aurélie Perrin • Claudine Basset-Mens • Joël Huat • \\ Wilfried Yehouessi
}

Accepted: 11 July 2014 /Published online: 22 August 2014

(C) INRA and Springer-Verlag France 2014

\begin{abstract}
In sub-Saharan Africa, urban farmers have recently intensified the production of vegetables to cope with the increasing food demand. As a consequence, such an intensification may lead to potential risks for the environment and human health. There is therefore a need for an integrated evaluation of urban agricultural practices. Here, we studied tomato production in Benin cities. We measured performances and the environmental risks. We have monitored 12 cropping systems during 6 months and we calculated the pesticide treatment frequency index (TFI), the nutrient budgets, and the field emissions. Our results show that yields were low and variable, averaging at 9,533 kg.ha ${ }^{-1}$ and ranging from 0 to 21,163 kg.ha ${ }^{-1}$. The average TFI for pesticides was 8.9. The maximum TFI of 25 was observed for an insecticide applied weekly at 2.3 times the official rate. We observed an excess of the average nutrient budget of $120 \mathrm{~kg} \mathrm{~N}$ and $84 \mathrm{~kg} \mathrm{P} . \mathrm{ha}^{-1}$. In conclusion, our study of urban tomato production revealed poor practices and high risks for health and the environment.
\end{abstract}

Keywords Urban agriculture - Life-cycle inventory · Typology $\cdot$ Cropping system data $\cdot$ Treatment frequency index $\cdot$ Nutrient budget

\section{Introduction}

In sub-Saharan Africa, the urban population is projected to increase from 400 to 750 million between 2010 and 2030

A. Perrin $(\bowtie) \cdot$ C. Basset-Mens $\cdot$ J. Huat

UPR Hortsys, CIRAD, F-34398 Montpellier, Cedex 5, France

e-mail: aurelie.perrin@cirad.fr

J. Huat

Africa Rice Center, 01 BP 2031, Cotonou, Benin

W. Yehouessi

Faculté des Sciences Agronomiques, Université d'Abomey-Calavi,

Cotonou, Benin
(UN-HABITAT 2013). Urban agriculture holds the most potential to feed this increasing population, curb urban poverty, and ensure food security (Abdulkadir et al. 2012). To face the increasing demand of fresh products from the cities and the scarcity of land available for agriculture, urban farmers and especially vegetable gardeners intensified their practices, i.e., multiple crop cycles in one year, continued cropping for many years. Such intensive practices led to improper uses of fertilizers and pesticides (Drechsel and Zimmermann 2005; de Bon et al. 2010). Such intensive practices started to lead to deleterious environmental consequences (de Bon et al. 2010; Abdulkadir et al. 2012). In this concerning context, a comprehensive environmental assessment, representative for a diversity of agricultural practices for urban horticulture in Africa is required.

Comprehensive environmental assessments for agricultural products have been successfully based on life cycle assessment (LCA) which is a multicriteria and global approach with normalized principles and framework (ISO 14040 2006; ISO 14044 2006). LCA is based on a comprehensive environmental inventory, so-called life cycle inventory (LCI), which compiles all resources that are needed for and all emissions that are released by the specific system under investigation and relates them to the function of the system (Haas et al. 2000). However, this powerful decision helping tool has almost never been used to assess the environmental impacts of vegetables in tropical contexts (Sim et al. 2007; Mila i Canals et al. 2008). In horticultural production systems, high variations between farms regarding environmental impacts have been observed even under homogenous production situations (Mouron et al. 2006). Applying the LCA framework to tropical vegetables constitutes the most challenging task for practitioners because of the considerable variations in the resource use and performances between farms of the same main activity and also because of the extreme scarcity of data in such contexts.

By quantifying all inputs and outputs including emissions to the environment, the LCI step of LCA offers a consistent 
framework to study the performance and environmental risks of urban horticulture systems. Indeed, emissions to the environment constitute risks, or hazards, for receiving ecosystems. However to date, the literature on African urban horticulture does not offer sufficient data including quantified inputs and outputs as required for a proper life cycle inventory. Although several studies addressed environmental issues of urban horticulture in Africa, they focused either on fertilizers or pesticides. According to a recent review, most vegetable growers in sub-Saharan Africa and the totality of Beninese ones apply pesticides. Moreover, pesticide use is expected to increase due to urbanization, the prevalence of the informal sector and climate change (de Bon et al. 2014). The few studies analyzing pesticide use in such contexts suggested poor pesticide practices, i.e., frequent treatments with large rates of unsuitable active substances with respect to the target pest (Rosendahl et al. 2009; Ahouangninou et al. 2012). In Benin for example, a clear identification of the pests is not part of the key factors influencing the use of pesticides by the farmers (de Bon et al. 2014). Regarding fertilizers, large quantities of nutrients in the form of chemical fertilizers and livestock manure are applied to urban gardens (Diogo et al. 2010; Sangare et al. 2012). Due to low yields, an important part of nutrient input is lost to the environment (Predotova et al. 2010, 2011; Lompo et al. 2012). Nutrient emissions such as $\mathrm{NH}_{3}$, $\mathrm{N}_{2} \mathrm{O}, \mathrm{NO}_{3}$, and phosphorus often contribute considerably to the environmental risk associated to urban cropping systems. However, it is often difficult to estimate rates of nitrogen and phosphorus released to the air and to the water. Measuring emission rates directly on field is time and cost-demanding, especially when considering the variability of emissions at small scale (Bussink and Oenema 1998; Stehfest and Bouwman 2006). Despite first evidences of probable human health and environmental risks, the lack of quantified and comprehensive data on crop protection practices for urban cropping systems in Africa (Fig. 1) hampered any attempt of assessment.

Furthermore, recent LCA guidelines such as the ILCD handbook (European Commission 2010) have emphasized

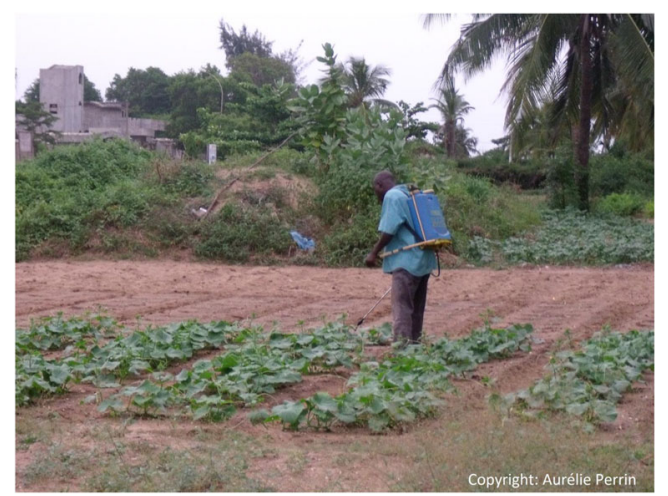

Fig. 1 Pesticide application by a farmer on an urban garden at Cotonou (November 2011) the importance of evaluating the quality of LCI data in terms of reliability, completeness, and representativeness of the studied function. Although recent papers showed interesting attempts to account for the diversity between horticulture farms (Cellura et al. 2012; Ingwersen 2012), most LCA studies still lack a comprehensive discussion of the representativeness and quality of LCI data and this recommended data quality assessment appears insufficiently applied. This is particularly detrimental considering the wide diversity and variability of those systems and the tremendous lack of data.

This paper presents a comprehensive life cycle inventory for a typical African urban garden case study showing extreme data scarcity. Our objectives were (1) to quantify the performances and the environmental risks associated to urban tomato gardens in Benin and (2) to assess the quality of data for the sake of environmental assessment.

\section{Materials and methods}

\subsection{Urban tomato gardens in Benin}

Our data collection took place in Southern Benin from September 2011 to April 2012 which corresponds to the long dry season. In this region, urban gardens are essentially located within or in the surrounding of three coastal cities, Cotonou, Ouidah, and Grand-Popo, thanks to the accessibility to water for irrigation and the proximity of urban markets. Those urban gardens present sandy soils except for those located along the rivers or lagoons where the soil can content high rates of silt and clay. Among vegetable productions, the out-of-season tomato is one of the highest value crops grown by urban farmers, and aims at providing cash flow for urban farmers. Due to low rainfall and high pest pressure, the long dry season is not favorable to tomato production. However, the tomato being the base for many traditional dishes, the important demand associated to high prices on the market explains this out-of-season tomato production. Unlike the seasonal tomato production mostly located in rural areas, the out-of-season production requires irrigation. In addition, large amount of fertilizers and pesticides are applied to increase yields and cope with the high land pressure in urban area. Those cropping system specificities are of major importance for the environmental performance of tomato production in urban gardens in Benin.

With the support of the communal extension services of the three cities, we recorded 40 urban farmers growing out-ofseason tomatoes during the 2011-2012 season. We implemented a typology of the out-of-season tomato cropping systems- a cropping system being defined as a crop grown with a specific soil, climate, and management. This typology addressed a dual-purpose: (1) to allow the sampling of representative cropping systems for the population to which applying a 
detailed monitoring (section 2.2), (2) to allow the production of representative scenarios (section 2.3). To this aim, we identified three criteria easily observable and quantifiable on farms-type of irrigation system; type of water resource; and planting date-with the help of a panel of tropical horticultural experts from CIRAD (the French research center for agriculture in developing countries), from INRAB (the Beninese national research institute of agriculture), and from the governmental extension service (CeRPA), identified as the best mean to access farmers. For each criteria, three modalities were also identified: (1) type of irrigation system: manual, hose, and sprinkler (being the most advanced system); (2) type of water resource: depression (the most restricted resource), drilling, and river; (3) planting date: early (September), median (November), and late (January). Using the three criteria of the typology, 10 cropping system types representative for the diversity of out-of-season tomato cropping systems were identified over the 40 farmers of the population (Fig. 2).

\subsection{Sampling cropping systems for monitoring}

To comply with the need for a good representation of the tomato cropping systems diversity identified through our typology and the time required for a quality monitoring, the sampling consisted in the selection of 12 cropping systems. To capture the main changes in daily cultural operations and to record precisely occasional operations, we had to interview farmers every 2 weeks. We could visit two farmers in 1 day and, we needed 2 days every week to check the data and to fill the database. Moreover, to ensure the best quality of data, three feasibility criteria were added to the typology: (1) selecting farmers able to provide detailed information on their practices, (2) selecting tomato fields at the beginning of the crop cycle and, (3) selecting fields with healthy crops to ensure as much as possible to reach the harvest stage. Cropping system types with manual irrigation and crop cycles occurring during the median period had high pest attacks at the nursery stage, and crops were not transplanted. Moreover, late crop cycle types were not advanced enough at the time of the data collection process and were therefore discarded. Consequently, our sample of 12 cropping systems included only six cropping system types.

The early cropping system type with manual irrigation and water from depression gathered two systems with insecure land tenure preventing any investment in infrastructures, i.e., drilling, pumps, and pipes. This insecurity was increased by
Fig. 2 Representative environmental inventories for out-of-season tomato cropping systems in studied urban areas in Benin (2011-2012 - Cotonou, Ouidah, Grand Popo), built on a typology based on three criteria easily observable and quantifiable on farms: irrigation system, water resource, and planting date of the tomato plots. Within the population gathering 13 ha of urban gardens, we identified 10 cropping system types. Twelve cropping system were selected for monitoring. Data from those 12 cropping systems were aggregated per type. Their weighted mean based on weighting factors on area basis was used as a proxy of the population

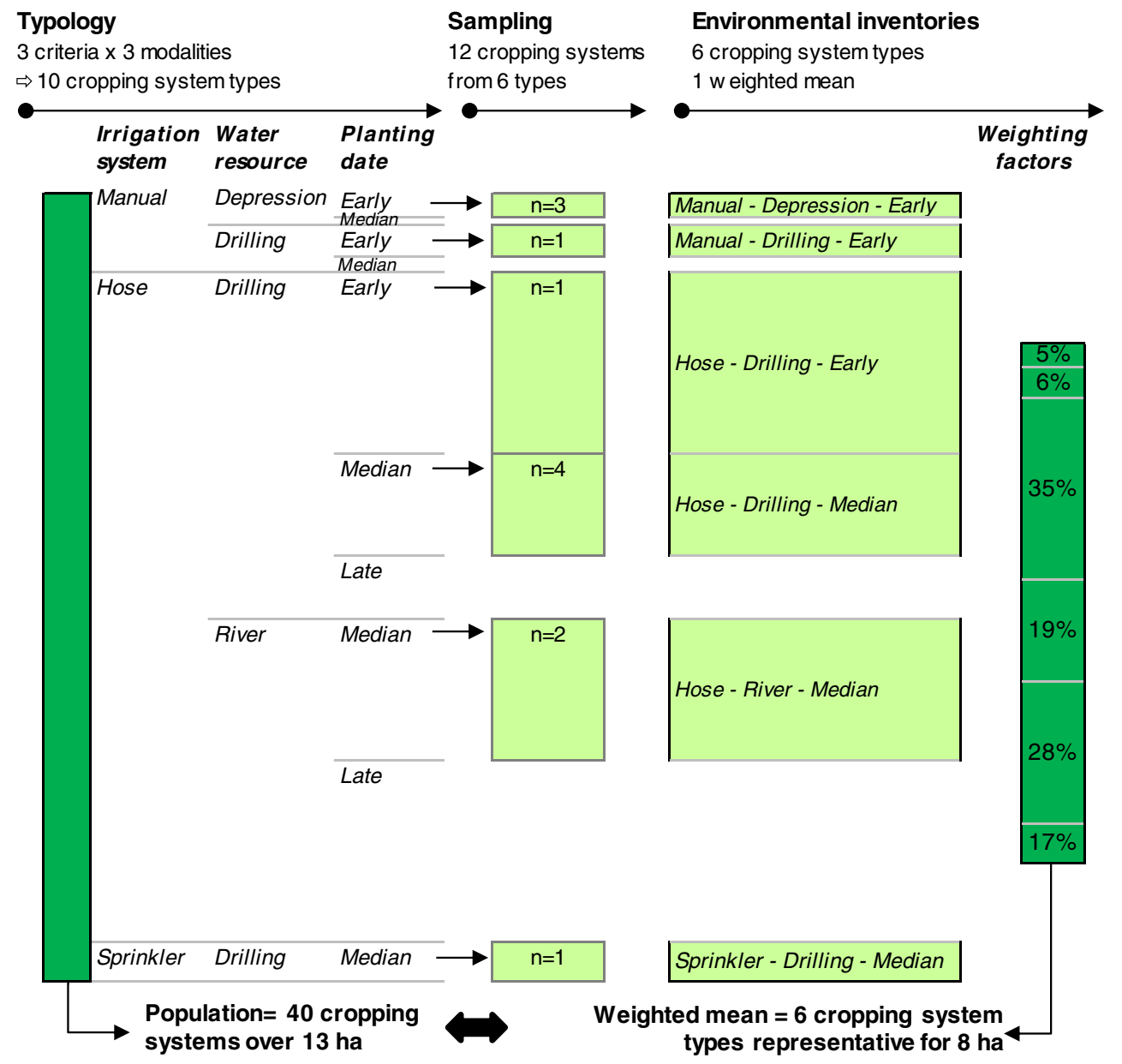


the water resource, i.e., depression which may dry up very shortly after the rainy season. The early cropping system with manual irrigation and water from drilling was typical of areas with low-cost and plentiful labor, i.e., in large cities. As a rule, cropping system types with manual irrigation mainly gathered farmers located at Cotonou with small farm area due to high land pressure. The cropping system types with hose irrigation and water from drilling corresponded to the most common practices for farmers located at Ouidah and Grand-Popo thanks to medium to lower land pressure than at Cotonou. Indeed, infrastructures reduced the need for labor and allowed to grow larger plots. The low rainfall and the high pest pressure during the early period of the studied 2011-2012 season prevented farmers from growing plantlets in August, reducing our sample to one system for this type. However, four cropping systems with hose irrigation and water from drilling grown during the median period, i.e., from November to March with nursery in October were sampled. The median cropping system type with hose irrigation and water from river was not very common in the area, due to the flood of the rainy season and the important labor need to cultivate clay soils. However, this type gathered large farms thanks to low land pressure on those areas sensitive to flood. Two cropping systems were sampled within this type. Finally, the median cropping system type with sprinkler irrigation and water from drilling was not very common either in the area due to important investment requirements. However, one system was sampled in this type which can be considered as the most innovative cropping system studied.

\subsection{Cropping system data for environmental inventories}

For these 12 cropping systems, we collected data in two steps. First, farmers were asked to describe systematically each field operation: date, plot concerned, container, measure, and machine used. To guarantee the accuracy of the data and to avoid language or cultural misunderstanding issues, farmers' declarations were collected by advisors from the communal extensions services involved in the partnership. Then, a second step consisted in quantifying input flows. Another operator was in charge of expressing the farmer's declarations into quantified flows expressed in standard units per hectare, using timer, scales, and measuring cups.

Inventory data were presented for the cropping system types represented in our sample and for their weighted mean (Fig. 2). Data collected from the 12 cropping systems in Benin were aggregated into types with horizontal averaging, i.e., each parameter was considered as independent. The weighted mean was calculated as the weighted average of types according to their relative weight for the population on an area-basis. For each type, its relative weight was calculated as the ratio between the cultivated area of the specific type and the sum of the cultivated areas of represented types within the population.
To analyze the dispersion of types around this weighted mean, we calculated the coefficient of variation $(\mathrm{CV})$ around the mean value of each type.

For pesticides, applied commercial products were composed by either a unique active substance or by a mix of two active substances, e.g., dimethoate/cypermethrin. Amounts of products applied per crop cycle were recorded according to farmer's declaration. We calculated the treatment frequency index (TFI) per crop cycle for each pesticide corresponding to the sum of official European approved rates applied (van Bol et al. 2003). In practice, we divided the amount of active substance applied by its official rate (E-phy 2013). European approved rates were used because of their availability for a large range of active substances and can be considered valid for our case study as pesticide recommendations in Africa were based on developing countries regulations (de Bon et al. 2014). This indicator allowed us to compare pesticide uses regardless of the nature of the product or the number of actual applications. For each product, a TFI above 1 either meant that more than one application was done or that the product was applied at an excessive rate.

Nutrient balances were calculated using the steady state hypothesis of organic matter stability (nitrogen from soil organic matter was neglected). Basically, an element balance equation for any system can be stated as

$\Delta P_{\mathrm{E}}=I_{\mathrm{E}}-O_{\mathrm{E}}$

where $\Delta P_{\mathrm{E}}, \mathrm{I}_{\mathrm{E}}$, and $O_{\mathrm{E}}$ stand for the change in the pool, the input, and the output of element $\mathrm{E}$, respectively. Applied to our systems for nitrogen and phosphorus, Eq. (1) can be modified to Eq. (2) with inputs at the left hand and outputs at the right hand:

$$
\begin{aligned}
& \text { MinFert }_{\mathrm{N} \& \mathrm{P}}+\text { OrgFert }_{\mathrm{N} \& \mathrm{P}}+\text { Rain }_{\mathrm{N \& P}}+\operatorname{Irr}_{\mathrm{N \& P}} \\
& =\text { Export }_{\mathrm{N} \& \mathrm{P}}+\text { Volat }_{\mathrm{NH} 3}+\text { Denit }_{\mathrm{N} 2 \mathrm{O}}+\text { Leach }_{\mathrm{NO} 3 \& P} \\
& \quad+\text { Denit }_{\mathrm{N} 2}+\Delta \text { Soil }_{\mathrm{N} \& \mathrm{P}}
\end{aligned}
$$

In tomato urban gardens, nutrients were provided through poultry manure as an organic fertilizer with high nutrient content, urea, or combined fertilizers with variable N:P:K ratios. Nitrogen and phosphorus inputs from mineral (MinFert ${ }_{\mathrm{N} \& P}$ ) and organic fertilizers (OrgFert ${ }_{\text {N\&P}}$ ) were calculated based on farmer's declaration referring to quantity of fertilizers applied and the nutrient content of these fertilizers.

For our systems, we set nutrient inputs from rain (Rain N\&P) and irrigation water ( $\operatorname{Irr}_{\text {N\&P }}$ ) to 0 . This amount could be significant if waste water was used for irrigation (Diogo et al. 2010). However, gardeners in Cotonou can easily reach fresh groundwater at a maximum depth of $2 \mathrm{~m}$ in any location and at any time of year. Therefore, wastewater is generally not used for irrigation purposes (Brock and Foeken 2006). 
Fresh yields were recorded according to farmer's declaration. Due to the lack of measured data, the exportation of nutrients in harvested tomatoes (Export N\&P) were assumed to content $0.15 \% \mathrm{~N}$ and $0.05 \% \mathrm{P}$ of fresh matter (Diogo et al. 2010). Fertilizer emissions were also estimated, using the best available methods used in LCA. For ammonia emissions from volatilization of mineral fertilizers and poultry manure (Volat $\mathrm{NH} 3$ ), emission factors from Bouwman and Van Der Hoek (1997) were used since they correspond to tropical conditions, i.e., $4 \%$ for NPK, $20 \%$ for poultry manure, and $25 \%$ for urea. We used emission factors from IPCC (2006) to estimate direct ( $1 \%$ of nitrogen inputs) and indirect $\left(1 \%\right.$ of $\mathrm{NH}_{3}$ emitted and $0.75 \%$ of $\mathrm{NO}_{3}$ emitted) nitrous oxide emissions from denitrification (Denit $\left.{ }_{\mathrm{N} 20}\right)$ and to estimate nitrate leaching $\left(\operatorname{Leach}_{\mathrm{NO} 3}\right.$ being $30 \%$ of nitrogen inputs). Given the lack of specific data on phosphorus emissions in tropical conditions, we followed the recommendations from Nemecek and Kägi (2007) to estimate phosphorus emissions from leaching and run-off (Leach ${ }_{\mathrm{P}}$ ). A part of the nitrogen inputs is emitted as $\mathrm{N}_{2}$ through denitrification (Denit ${ }_{\mathrm{N} 2}$ ) with no potential impact on the environment. To estimate this pool, we applied the emission factor of $9 \%$ of nitrogen input as suggested in Brentrup et al. (2000). The remaining nutrient pool in the soil $\left(\Delta\right.$ Soil $\left._{N \& P}\right)$ was further called nutrient surplus.

\subsection{Comparison with scenarios based on the literature}

The comparison and the validation of inventory data are essential for producing reliable LCA. Inventory data for our six cropping system types and their weighted mean were compared with agronomic data and measured field emissions from the literature. Seven published articles were identified as suitable for comparison, from which we built three scenarios.

We called the first one "Eritrea scenario", based on agronomic data collected by Asgedom et al. (2011) from a survey of 146 tomato producers located in five regions in Eritrea. Those five regional tomato systems differed from our case study as they were not exclusively located in urban gardens and some were partly rain fed. However, it is to our knowledge the only dataset providing crop lengths for nursery and plot and, crop densities associated to yields. We aggregated data related to these five tomato systems under the "Eritrea scenario".

The second comparative scenario was the "Tomato scenario" based on two studies (Diogo et al. 2010; Lompo 2012). Diogo et al. (2010) collected agronomic data from a 24-month monitoring of ten urban gardens at Niamey (Niger) between 2006 and 2009. Lompo (2012) collected agronomic data from a 24-month monitoring of two urban gardens (Kodéni and Kuinima) at Bobo Dioulasso (Burkina Faso) between 2008 and 2010. These systems were very similar to our case study, even though tomato was preferably grown during the rainy season (March-July) and was irrigated using cans. We extracted from these two studies data related to six tomato crop cycles and aggregated them under the "Tomato scenario". Three high input cycles and one low input cycle were selected in Niger; the two cycles from Kodéni were selected in Burkina Faso.

The last scenario was the "Rotation scenario", based on three studies dedicated to emission assessments (Predotova et al. 2010). These authors measured gaseous or leached emissions for an annual succession of crops from a selection of monitored urban gardens from the previous studies, namely Goudel and Yantala in Niger, and Kodeni and Kuinima in Burkina Faso. Based on our case study, one tomato cropping cycle lasts for about 3 months, allowing four crop cycles on average per year. For comparison with our data, we assumed that a 3-month tomato cropping cycle corresponded to $25 \%$ of the length of an annual rotation. We extracted and aggregated data related to these four urban gardens and divided them by a factor 4 under the "Rotation scenario".

\subsection{Data quality assessment}

We evaluated our dataset for urban tomato gardens in Benin based on recommendations from the ILCD handbook (European Commission 2010), i.e., the most recent guidelines for life cycle assessment. This data quality assessment is based on six data quality indicators namely, technological representativeness (TeR), geographical representativeness (GeR), time-related representativeness ( $\operatorname{TrR})$, completeness $(\mathrm{C})$, precision and uncertainty $(\mathrm{P})$, and methodological appropriateness and consistency (M). A self-evaluation based on performances and limitation of our dataset allowed us to score our dataset for each indicator independently with 1 being the best score and 5 the worst. The overall quality of the dataset can be derived from the quality rating of the various quality indicators based on Eq. 3:

$\mathrm{DQR}=\frac{\mathrm{TeR}+\mathrm{GeR}+\mathrm{TrR}+C+P+M+X_{\mathrm{w}} \times 4}{i+4} o$

with $X_{\mathrm{w}}$, the weakest quality level obtained among the data quality indicators and $i$ the number of indicators scored.

\section{Results and discussion}

\subsection{Variable and low tomato yields}

Overall, the crop yields of urban tomato gardens were low and variable but in the same range as the yields observed in literature scenarios. The weighted mean presented a yield slightly lower than that for the "Eritrean scenario" (9,533 vs. 
10,342 kg.ha ${ }^{-1}$ ) and much lower than that for the "Tomato scenario" (19,342 kg.ha-1).

As a result of up to six harvests in our case study, yields ranged from 0 to $21,163 \mathrm{~kg} \cdot \mathrm{ha}^{-1}$ across cropping system types (Table 1$)$. The high variability of yields $(\mathrm{CV}=80 \%)$ could be explained by non-optimal farmers' practices leading to severe pest damages. Compared to similar tomato cropping systems from the literature (Asgedom et al. 2011), the short crop lengths ( 78 vs. 105 days) indicated that farmers had to reduce their crop cycles, limiting the potential yield. Median crop cycles showed the shortest crop lengths and the lowest yields suggesting higher pest pressure during this period or poorer crop protection management.

\subsection{A diversity of irrigation management}

Large volumes of water and amounts of energy were used for irrigation across urban tomato gardens but they also showed a high variability. The water volume applied was greater for the weighted mean than for the "Tomato scenario" $(4,825$ vs. $3,185 \mathrm{~m}^{3} \mathrm{ha}^{-1}$ ), mostly due to lower rainfall in our case study (129 vs. $377 \mathrm{~mm}$ per crop cycle). The high coefficient of variation across types (60 vs. $1 \%$ for the "Tomato scenario") resulted from the high diversity in irrigation infrastructures and soil type characteristics. Indeed, these aspects did not vary across systems from the "Tomato scenario" which present only manual irrigation and sandy loam soils.

The extremely high volume applied for cropping systems with manual irrigation and water from drilling can be explained by the intermediary water tank leading to water evaporation during the storage period (Table 1). The small volume applied for cropping systems using water from river can be explained by clay soils common within this type located in the surrounding of rivers. Those soil types had greater field capacity than sandy soils. Finally, the sprinkler irrigation system was associated to a smaller volume of water used than other irrigation systems.

The weighted mean had a fuel consumption of $0.81 \mathrm{per} \mathrm{m}^{3}$ of water input with a coefficient of variation of $58 \%$. Cropping systems with manual irrigation and water from depression did not use any pump, resulting in nil fuel consumption. For the other types, i.e., cropping systems with water from drilling and river, variations of fuel consumption were related to local differences in water table depth (from 0 for river to $10 \mathrm{~m}$ for the deeper drilling) and the water flow of pumps (from 1,800 to $3,6001 . h^{-1}$ ).

\subsection{Crop protection: frequent applications of pesticides} at excessive rates

Crop protection practices revealed high and variable treatment frequency (TFI) indexes especially for insect control. Farmers systematically applied insecticides while the use of pesticides for disease and nematode control was more occasional. High TFI values highlighted both high frequencies of application and the application of excessive rates compared to official approved rates.

For insects' control, the weighted mean presented a high treatment frequency index of 8.9 with a high variability across types (Fig. 3a). Considering a crop length of 78 days (Table 1), a TFI of 8.9 corresponds to one insecticide application every 9 days. It means that treatments were repeated before the end

Table 1 Cropping systems over one tomato crop cycle for the six cropping system types and the weighted mean, compared with two scenarios from the literature

\begin{tabular}{|c|c|c|c|c|c|c|c|c|c|c|}
\hline $\begin{array}{l}\text { Irrigation } \\
\text { system }\end{array}$ & $\begin{array}{l}\text { Water } \\
\text { resource }\end{array}$ & $\begin{array}{l}\text { Planting } \\
\text { date }\end{array}$ & $n$ & $\begin{array}{l}\text { Rainfall } \\
\mathrm{mm}\end{array}$ & $\begin{array}{l}\text { Irrigation } \\
\mathrm{m}^{3} \cdot \mathrm{ha}^{-1}\end{array}$ & $\begin{array}{l}\text { Fuel consumption } \\
1 . \mathrm{m}^{-3} \text { of water }\end{array}$ & $\begin{array}{l}\text { Nursery } \\
\text { length days }\end{array}$ & $\begin{array}{l}\text { Crop length } \\
\text { days }\end{array}$ & $\begin{array}{l}\text { Density } \\
\text { plants.m }\end{array}$ & $\begin{array}{l}\text { Fresh yield } \\
\text { kg.ha }\end{array}$ \\
\hline \multirow[t]{2}{*}{ Manual } & Depression & Early & 3 & 138 & 4,765 & 0 & 36 & 75 & 3.7 & 5,787 \\
\hline & Drilling & Early & 1 & 9 & 10,412 & 0.6 & 63 & 79 & 2.7 & 7,875 \\
\hline \multirow[t]{3}{*}{ Hose } & Drilling & Early & 1 & 154 & 5,340 & 1.5 & 21 & 92 & 7.4 & 21,163 \\
\hline & Drilling & Median & 4 & 144 & 6,048 & 0.6 & 21 & 73 & 3.8 & 1,873 \\
\hline & River & Median & 2 & 147 & 2,611 & 0.4 & 28 & 68 & 3.4 & 3,604 \\
\hline Sprinkler & Drilling & Median & 1 & 1 & 2,621 & 0.6 & 37 & 67 & 3.7 & 0 \\
\hline \multirow{2}{*}{\multicolumn{3}{|c|}{ Weighted mean }} & 6 & 129 & 4,825 & 0.8 & 27 & 78 & 5.2 & 9,533 \\
\hline & & & $\mathrm{cv} \%$ & 57 & 62 & 58 & 57 & 12 & 32 & 80 \\
\hline \multirow{2}{*}{\multicolumn{2}{|c|}{ Eritrea scenario }} & & 5 & na & na & na & 31 & 105 & 4.9 & 10,342 \\
\hline & & & $\mathrm{cv} \%$ & na & na & na & 13 & 14 & 34 & 26 \\
\hline \multirow{2}{*}{\multicolumn{2}{|c|}{ Tomato scenario }} & & 6 & 377 & 3,185 & na & na & na & na & 19,192 \\
\hline & & & $\mathrm{cv} \%$ & 74 & 1 & na & na & na & na & 110 \\
\hline
\end{tabular}

The "Eritrea scenario" corresponds to the average of five tomato cropping systems in Eritrea (Asgedom et al. 2011), and the "Tomato scenario" corresponds to the average of six tomato cropping systems from urban gardens in West Africa (Diogo et al. 2010; Lompo 2012). In urban gardens, yields were highly variable as shown by the coefficients of variation (cv). The short crop lengths and the low yields resulted from pest attacks. Some data were not available in reviewed papers (na) 
of the persistence period, e.g., 20 days for pyrethroids. This result agrees with records on a weekly frequency of insecticide applications and validates the assumption of preventive practices (de Bon et al. 2014). The highest TFI shown by early cropping systems with manual irrigation and water from drilling $(\mathrm{TFI}=25)$ resulted from frequent applications at excessive rates per application, i.e., one treatment every week at 2.3 -fold the official rate. Overall, the greatest TFI resulted mainly from the use of pyrethroids, i.e., cypermethrin, lambda cyhalothrin and deltamethrin. The main pest for tomato urban garden was Helicoverpa armigera, also called the "cotton bollworm" which is sensitive to pyrethroids. However, farmers struggled in identifying pests, leading to inadequate choice and low efficacy of products. For Tetranychus evansi also called the "red spider mites", no effective acaricide was available. Despite several insecticide treatments, farmers may lose the whole harvest from early Tetranychus evansi attack.

For diseases control (Fig. 3b), the weighted mean presented a TFI of 2.1 with a lower variability across types compared to other target pests. The highest TFI shown by cropping systems with sprinkler irrigation resulted from frequent applications at excessive rates per application, i.e., three applications at 1.3fold the official rate. Overall, the largest TFI resulted from several uses of maneb, thiophanate methyl, or mancozeb. Several diseases caused tomato losses, e.g., Fusarium oxysporum lycopersici or Sclerotinia sclerotiorum. However, many farmers could not distinguish fungus and bacterial symptoms from virus symptoms such as the tomato yellow leaf curl virus transmitted by the whitefly Bemisia tabaci, leading again to inadequate choice and low efficacy of products.

For nematodes control (Fig. 3c), the weighted mean presented a lower TFI $(\mathrm{TFI}=1.7)$ compared to other target pests but highly variable across types partly due to the absence of treatments for the three early cropping system types. It appeared that only on median crop cycles, pesticides against nematodes were applied. The highest TFI reached for cropping systems with sprinkler irrigation resulted from an excessive rate per application, i.e., one application at 4.9-fold the official rate. The highest TFI were associated to the use of carbofuran and terbufos.
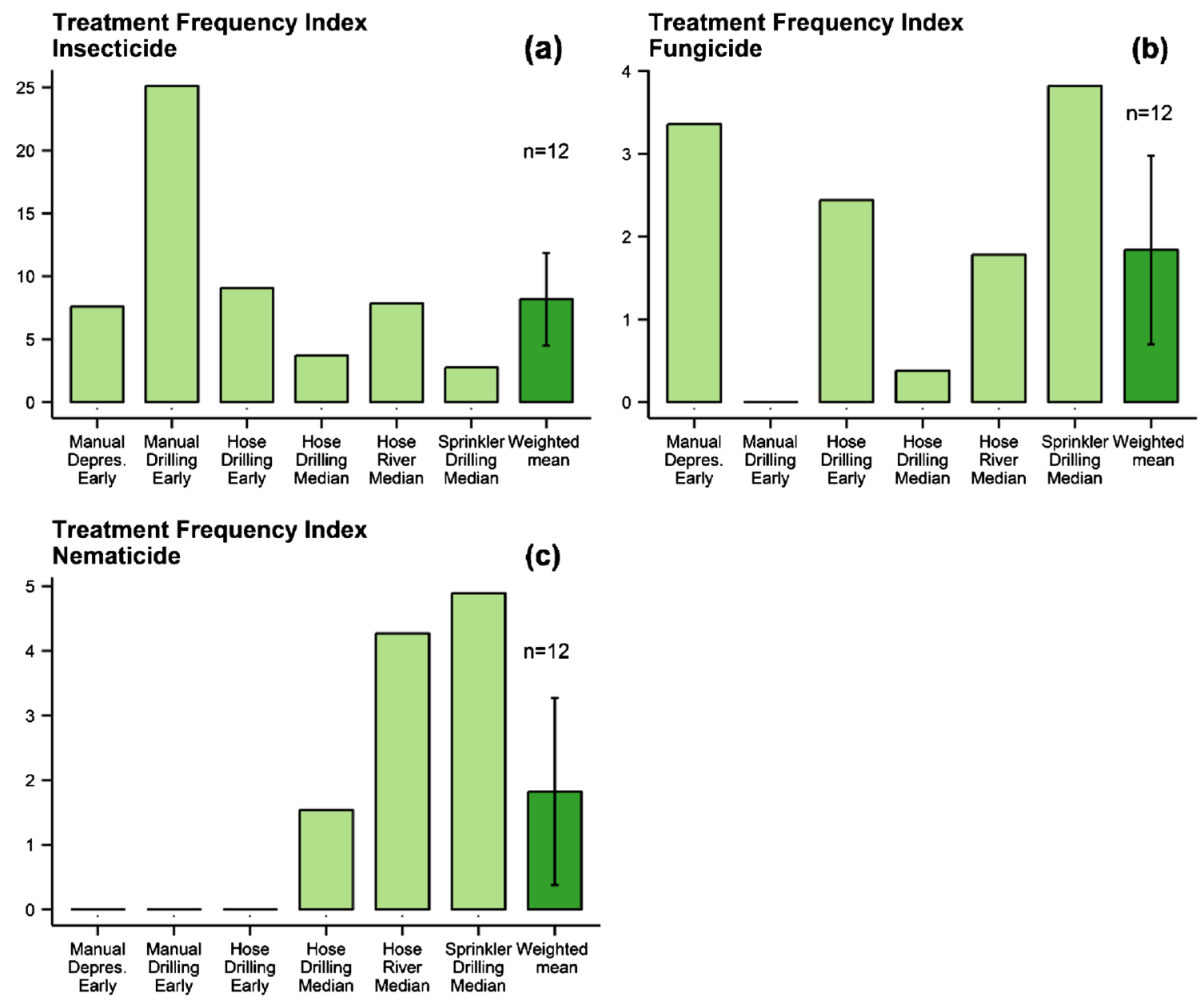

Fig. 3 Treatment frequency index (TFI) for the six cropping system types and the weighted mean for out-of-season tomato in Benin. TFI were higher for insect control (a) than for disease (b) or nematode control

(c), and varied much across cropping systems types. These results highlight a systematic use of insecticides, and excessive rates for all pesticides 
Our dataset revealed crop protection practices with high risks for the environment and for human health. The orders of magnitude of treatment frequency index found in our study are in agreement with the high number of pesticide applications recorded from studies based on a larger sample of urban gardeners, i.e., superior to 100 in South-Benin (Ahouangninou et al. 2011) and Senegal (Cissé et al. 2003). In addition, our results suggested that the most intensive crop protection practices were not associated to better yields. Among many causes identified for poor pesticides practices (de Bon et al. 2014), the unsuitability of the product to the problem source is of particular importance for tomato urban gardens in Benin. We also noticed that high TFI were often associated to active substances with low official rates, i.e., pyrethroids, thiophanate methyl, maneb, mancozeb, terbufos, and carbofuran. It suggests that farmers had difficulties to extrapolate the dosage from a hectare basis to very small plot areas. According to Ahouangninou et al. (2012), the chlorpyrifos ethyl, the pyrethroids, the carbofuran, and the mancozeb present particularly high toxicological risks for the environment and for human health. Monitoring the fate of those active substances within the environment, e.g., following crops, soil, air, and water table would be of particular interest for better quantifying the risk associated to pesticide use for tomato urban gardens. In addition, the frequent use of active substances of the same family such as pyrethroids is responsible for the development of resistances of insects to pesticides (de Bon et al. 2014). Such resistance is of particular importance in urban areas as it endangers public health strategies against vectors of major infectious diseases such as Malaria (Yadouleton et al. 2009).

\subsection{Intensive fertilization management: important $\mathrm{N}$ and $\mathrm{P}$ surpluses}

Results showed that despite the inclusion of all emissions, the nitrogen and phosphorus surpluses remained large (120 kg N and $84 \mathrm{~kg} \mathrm{P.ha}{ }^{-1}$, respectively) and similar to surpluses observed in the literature (Fig. 4). These surpluses resulted from high inputs compared to crop exportations.

The weighted mean presented lower total nitrogen inputs $\left(271 \mathrm{~kg} \mathrm{~N} \mathrm{ha}^{-1}\right)$ than the "Tomato scenario" $\left(299 \mathrm{~kg} \mathrm{~N}^{-h^{-1}}{ }^{-1}\right)$ and the "Rotation scenario" (310 kg N.ha $\left.{ }^{-1}\right)$, due to lower amounts of mineral nitrogen. The higher surplus shown by "Tomato scenario" resulted from the absence of emissions in the nutrient budget calculation. Unlike for the nitrogen, the total phosphorus inputs for the weighted mean was higher than that for the "Tomato scenario" (90 vs. $\left.66 \mathrm{~kg} \mathrm{P} \mathrm{ha}^{-1}\right)$, due to higher amounts of organic phosphorus (66 vs. $39 \mathrm{~kg}$ P.ha ${ }^{-1}$ ). It seems that the relatively high phosphorus content of poultry manure was responsible for high phosphorus inputs in our Beninese systems. Cropping systems with manual or sprinkler irrigation, which were mainly located at Cotonou, presented relatively high amounts of nitrogen and phosphorus inputs compared to cropping systems with hose irrigation. This finding pleads for a correlation between the land pressure of cropping systems and the level of intensification for fertilization practices. Indeed, both small plots and the necessity for immediate return encourage intensive management practices.

The weighted mean presented higher nitrogen outputs than the "Tomato scenario" (14 vs. $\left.10 \mathrm{~kg} \mathrm{~N} \cdot \mathrm{ha}^{-1}\right)$. However, the weighted mean for nitrogen exported with harvest was lower than that for the "Rotation scenario" (14 vs. 124 kg N.ha ${ }^{-1}$ ). This difference resulted from the lower nutrient content of tomato compared with other vegetables as included in the "Rotation scenario".

Beninese cropping systems showed greater nitrogen losses from leaching $\left(\mathrm{NO}_{3}\right)$ than from volatilization $\left(\mathrm{NH}_{3}\right)$ and denitrification $\left(\mathrm{N}_{2} \mathrm{O}\right)$. The weighted mean presented a lower emission factor for $\mathrm{NH}_{3}$ than the "Rotation scenario" (14 vs. $39 \%$ of the total nitrogen inputs). This was observed despite the use in our study of emission factors for urea and manure obtained in tropical conditions (Bouwman and Van Der Hoek 1997) which were higher than in temperate conditions. However, observed differences between our $\mathrm{NH}_{3}$ estimates and measured $\mathrm{NH}_{3}$ emissions from the literature were probably not significant given the variability of the phenomenon at local scale. The weighted mean presented a lower emission factor for $\mathrm{N}_{2} \mathrm{O}$ than the "Rotation scenario" ( 1 vs. $15 \%$ of the total nitrogen inputs). By contrast, the weighted mean presented a higher emission factor for $\mathrm{NO}_{3}$ than the "Rotation scenario" ( 30 vs. $1 \%$ of the total nitrogen inputs). Using estimation methods in our case study rather than measurements most likely led to an underestimation of $\mathrm{N}_{2} \mathrm{O}$ emissions and an overestimation of $\mathrm{NO}_{3}$ leaching even considering variations. Finally, phosphorus emissions were very low for our study as for the "Rotation scenario". However, this does not anticipate the associated potential impact on eutrophication, phosphorus being a limiting factor in natural ecosystems.

The large surpluses suggest that emissions could occur beyond the crop cycle duration in relation to the large pools of $\mathrm{N}$ and $\mathrm{P}$ stored in soils. The commonly used assumption of stability of the soil organic matter appears questionable for urban tomato gardens which are often recently settled and intensified cropping systems. This result raises the question of the fate of these nutrients surpluses after harvest. In addition to nutrients accumulation in soil, excessive rates of fertilizers also lead to the accumulation of non-nutritious components such as heavy metals (Atidegla et al. 2012). Monitoring the fate of those components within the environment, e.g., following crops, soil, air, and water table, would be of particular interest for better quantifying the risk associated to fertilizer use for tomato urban gardens. Finally, our nitrogen budget also showed that neglecting $\mathrm{N}_{2}$ emissions as was the case in the reviewed literature, can lead to large underestimations of nitrogen outputs. 


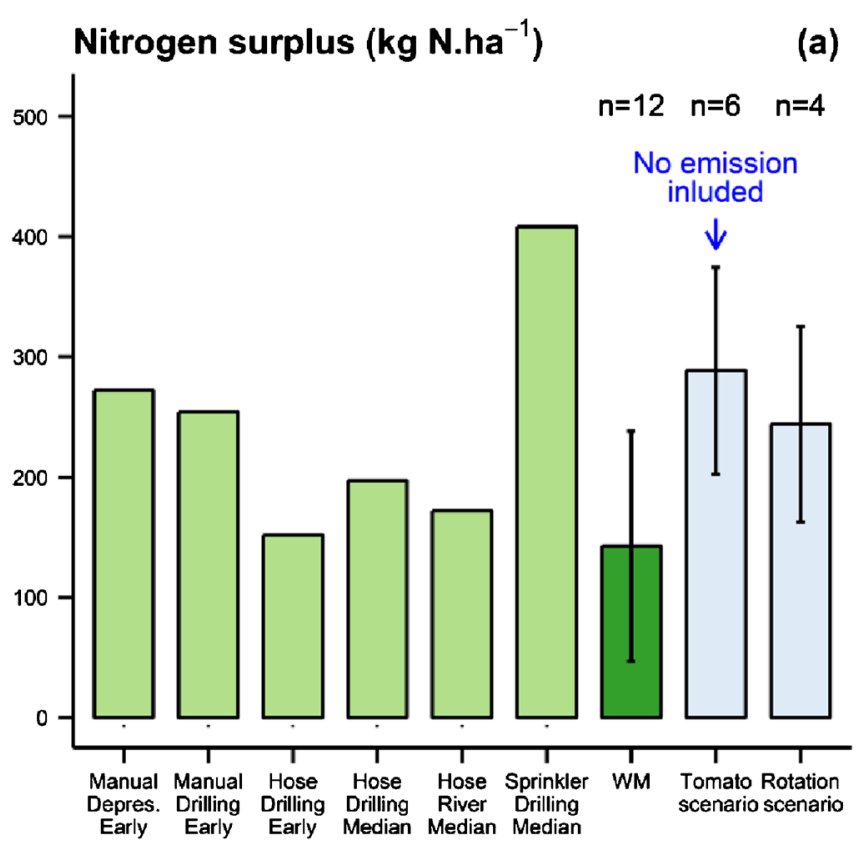

Fig. 4 Nitrogen (a) and phosphorus (b) surplus for the six types and the weighted mean (WM), compared with two scenarios from the literature. The "Tomato scenario" corresponds to the average of six tomato cropping systems from urban gardens in West Africa (Diogo et al. 2010; Lompo 2012) for which no field emissions data were available. The "Rotation

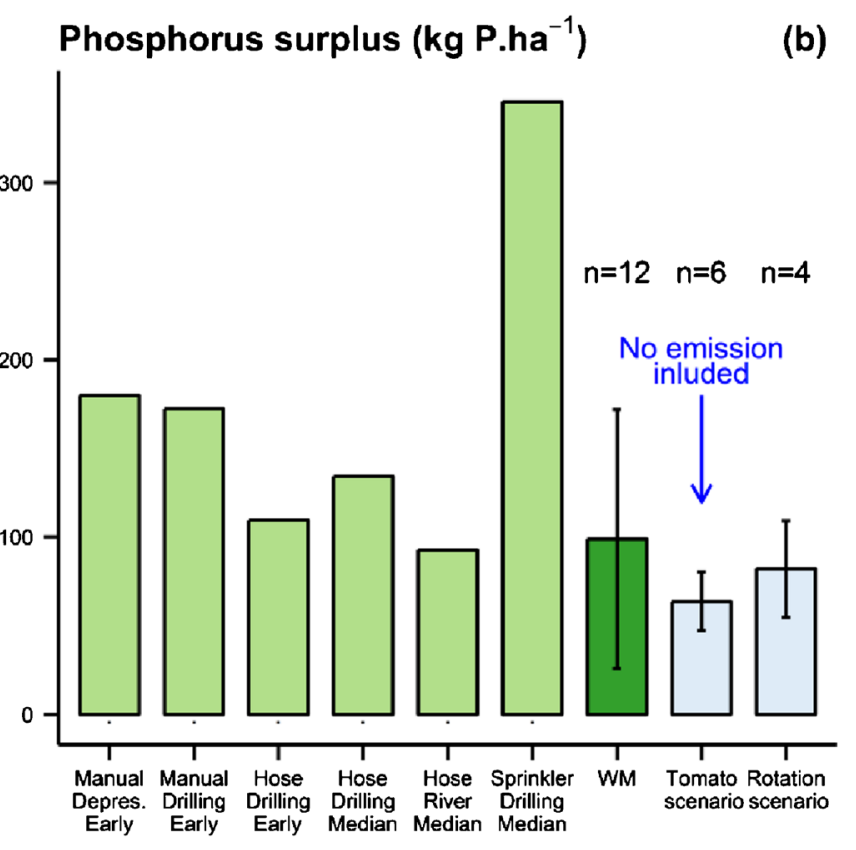

scenario" corresponds to $25 \%$ of the average of four annual rotations from urban gardens in West Africa (Predotova et al. 2010, 2011; Lompo et al. 2012). Our study shows large surplus comparable to the literature. These results highlight excessive fertilizer rates associated to low crop exportations, leading to large field emissions

Table 2 Data quality assessment of our life cycle inventory (LCI) dataset for urban tomato gardens in Benin

\begin{tabular}{|c|c|c|c|}
\hline Quality Indicator & Definition & Performances and limitations of our dataset & Self-evaluation \\
\hline $\begin{array}{l}\text { Technological } \\
\text { representativeness }\end{array}$ & $\begin{array}{l}\text { "Degree to which the data set } \\
\text { reflects the true population of } \\
\text { interest regarding technology." }\end{array}$ & $\begin{array}{l}\text { - Representative for } 60 \% \text { of types } \\
\text { based on technological criteria } \\
\text { identified with an expert panel } \\
\text { - Representative for } 70 \% \text { of farmers' practices }\end{array}$ & 1 \\
\hline $\begin{array}{l}\text { Geographical } \\
\text { representativeness }\end{array}$ & $\begin{array}{l}\text { "Degree to which the data set } \\
\text { reflects the true population of } \\
\text { interest regarding geography." }\end{array}$ & - Representative for $60 \%$ of the production area & 1 \\
\hline $\begin{array}{l}\text { Time-related } \\
\text { representativeness }\end{array}$ & $\begin{array}{l}\text { "Degree to which the data set reflects } \\
\text { the true population of interest } \\
\text { regarding time/age of the data." }\end{array}$ & - Data collected especially for the study & 1 \\
\hline & & · Homogenous period (out-of-season) & \\
\hline Completeness & $\begin{array}{l}\text { "Share of flows that are quantitatively } \\
\text { included in the inventory." }\end{array}$ & $\begin{array}{l}\text { All flows were measured or estimated } \\
\text { based on a budget approach }\end{array}$ & 1 \\
\hline Precision and uncertainty & $\begin{array}{l}\text { "Measure of the variability of the data } \\
\text { values for each data expressed." }\end{array}$ & $\begin{array}{l}\text { - Farmer's declaration collected by local advisors } \\
\text { - Straightaway quantification and checking } \\
\text { - The variability between year could not } \\
\text { be quantified }\end{array}$ & 2 \\
\hline $\begin{array}{l}\text { Methodological } \\
\text { appropriateness and } \\
\text { consistency }\end{array}$ & $\begin{array}{l}\text { "The applied LCI methods and } \\
\text { methodological choices are in line } \\
\text { with the goal and scope of the data." }\end{array}$ & $\begin{array}{l}\text { - Methods selected for their validity for } \\
\text { tropical contexts } \\
\text { - No consideration of pesticides and } \\
\text { nitrogen fate after harvest }\end{array}$ & 2 \\
\hline $\begin{array}{l}\text { Overall data } \\
\text { quality rating }\end{array}$ & $\begin{array}{l}\text { Overall data quality calculated as } \\
\text { detailed in equation } 3\end{array}$ & $\begin{array}{l}\text { High quality } \leq 1.6 \text { Basic quality from } 1.6 \text { to } 3 \\
\text { Data estimate }>3\end{array}$ & 1.6 \\
\hline
\end{tabular}

The best score is 1 , the worst is 5 . The dataset was self-evaluated as high quality enabling its use for future environmental assessment. The overall data quality was hampered by the short duration of the monitoring ( 1 year) and the uncertainty associated to the methods used for field emission estimation 
3.5 Prospects for the life cycle assessment of urban tomato gardens in Benin

We succeeded at producing high quality data (Table 2) on tomato urban garden cropping systems in Benin to be used for life cycle assessment (LCA). Such dataset could only be achieved thanks to strong and multiple partnerships with locally established research organizations, extension services, and farmers. The two first partners provided expertise to cope with the lack of bibliography and selected criteria for the typology. Extensions services also provided a precious repertory of farmers which guaranteed an unbiased selection of cropping systems, along with expertise and references to ensure the quality of data. Finally, the farmers were able to answer to our questions although they had no written records. It enabled the creation of a complete dataset describing agricultural practices and resource use from sowing to the last harvest. With a capacity of monitoring 12 cropping systems, we could only cover $30 \%$ of cropping systems in number but $70 \%$ of the cropping system types which also represented $60 \%$ of the total cultivated area of tomato urban gardens in Benin (Fig. 2).

However, the dataset quality was partly reduced by the limited monitoring period and the absence of measured nitrogen emissions. Only 1 year of practices monitoring prevented us from analyzing interannual variations due to climatic or economic changes influencing tomato production in urban gardens. Field emissions were estimated at the crop cycle scale. Overall, this paper underlined environmental risks associated to fertilizers and pesticides fate with very likely emissions after harvest and long-term environment quality effects such as soil fertility, water table, and air pollution.

\section{Conclusions}

In this paper, we presented cropping system data and emissions estimates for representative environmental inventories of urban tomato gardens in Benin. We used a typology to sample 12 cropping systems within a population of 40 farmers. We analyzed the different inventory data for the range of cropping system types and for their weighted mean and compared them to comparable data from scenarios based on the literature. We then assessed the resulting inventory data according to consensual quality criteria as recommended by the ILCD Handbook from the European Commission.

Pesticide and fertilizer rates were variable and excessive. The weighted mean TFI were high, reaching 8.9 for insecticides, 2.1 for fungicides, and 1.7 for nematicides. Our results confirmed that pest control practices were likely to result from a lack of knowledge and technical support. It appeared that farmers encountered difficulties at applying pesticides at low rate. Beyond the large field emissions to the environment, the weighted mean nutrient budget showed large nutrient surpluses: $120 \mathrm{~kg} \mathrm{~N}$ and $84 \mathrm{~kg} \mathrm{P.ha}{ }^{-1}$. These large surpluses resulted from high nutrient inputs compared to crop exportations. Our results suggested a correlation between the land pressure of cropping systems, and the level of intensification for fertilization practices. Yields were low $\left(9,533\right.$ t.ha $^{-1}$ for the weighted mean) and also variable, due to random pest attacks. Irrigation management was particularly intensive with high and variable amounts of water inputs leading to large and variable fuel consumptions (most cropping system types using pumps). Overall, practices were not optimized and revealed low performance and high risks for the environment and for human health.

Our inventory data for urban tomato gardens in Benin were of high quality according to commonly used criteria in LCA. Allowing the selection of 12 representative cropping systems over a population of 40 farmers and their aggregation into six cropping system types, the typology allowed covering most of the geographical and technical diversity characterizing the population. These inventory datasets will be used in a comprehensive life cycle assessment to be presented in an upcoming paper.

\section{References}

Abdulkadir A, Dossa LH, Lompo D-P et al (2012) Characterization of urban and peri-urban agroecosystems in three West African cities. Int J Agric Sustain 10:289-314. doi:10.1080/14735903.2012. 663559

Ahouangninou C, Fayomi BE, Martin T (2011) Évaluation des risques sanitaires et environnementaux des pratiques phytosanitaires des producteurs maraîchers dans la commune rurale de Tori-Bossito (Sud-Bénin). Cah Agric 20:216-222

Ahouangninou C, Martin T, Edorh P et al (2012) Characterization of health and environmental risks of pesticide use in market-gardening in the rural city of Tori-Bossito in Benin, West Africa. J Environ Prot 3:241-248. doi:10.4236/jep.2012.33030

Asgedom S, Struik PC, Heuvelink E, Araia W (2011) Opportunities and constraints of tomato production in Eritrea. Afr J Agric Res 6: 956-967

Atidegla S, Agbossou E, Huat J, Glele Kakai R (2012) Contamination métallique des légumes des périmètres maraîchers urbains et péri urbains: cas de la commune de Grand-Popo au Bénin. Int J Biol Chem Sci 5:2351-2361. doi:10.4314/ijbcs.v5i6.15

Bouwman AF, Van Der Hoek KW (1997) Scenarios of animal waste production and fertilizer use and associated ammonia emission for the developing countries. Atmos Environ 31:4095-4102. doi:10. 1016/s1352-2310(97)00288-4

Brentrup F, Küsters J, Lammel J, Kuhlmann H (2000) Methods to estimate on-field nitrogen emissions from crop production as an input to LCA studies in the agricultural sector. Int J Life Cycle Assess 5:349-357. doi:10.1007/BF02978670

Brock B, Foeken D (2006) Urban horticulture for a better environment: a case study of Cotonou, Benin. Habitat Int 30:558-578. doi:10.1016/ j.habitatint.2005.02.001

Bussink DW, Oenema O (1998) Ammonia volatilization from dairy farming systems in temperate areas: a review. Nutr Cycl Agroecosyst 51:19-33. doi:10.1023/a:1009747109538 
Cellura M, Longo S, Mistretta M (2012) Life cycle assessment (LCA) of protected crops: an Italian case study. J Clean Prod 28:56-62. doi: 10.1016/j.jclepro.2011.10.021

Cissé I, Tandia AA, Fall ST (2003) Usage incontrôlé des pesticides en agriculture périurbaine: cas de la zone des Niayes au Sénégal. Cah Agric 12:181-186

Commission E (2010) International Reference Life Cycle Data System (ILCD) Handbook - general guide for life cycle assessment- detailed guidance. Joint Research Centre-Institute for Environment and. Sustainability, Luxembourg

De Bon H, Parrot L, Moustier P (2010) Sustainable urban agriculture in developing countries. A review. Agron Sustain Dev 30:21-32. doi: 10.1051/agro:2008062

De Bon H, Huat J, Parrot L et al (2014) Pesticide risks from fruit and vegetable pest management by small farmers in sub-Saharan Africa. A review. Agron Sustain Dev Online First Artic. doi:10.1007/ s13593-014-0216-7

Diogo RC, Buerkert A, Schlecht E (2010) Horizontal nutrient fluxes and food safety in urban and peri-urban vegetable and millet cultivation of Niamey, Niger. Nutr Cycl Agroecosyst 87:81-102. doi:10.1007/ s10705-009-9315-2

Drechsel P, Zimmermann U (2005) Factors influencing the intensification of farming systems and soil-nutrient management in the rural-urban continuum of SW Ghana. J Plant Nutr Soil Sci 168:694-702. doi:10. 1002/jpln.200521775

E-phy (2013) Catalogue des produits phytopharmaceutiques et de leurs usages des matières fertilisantes et des supports de culture homologués en France. In: Ministère l'agriculture l'agroalimentaire, Organ. Natl. la Prot. des Végétaux. http://e-phy. agriculture.gouv.fr/. Accessed 13 Jun 2013

Haas G, Wetterich F, Geier U (2000) Life cycle assessment framework in agriculture on the farm level. Int J Life Cycle Assess 5:345-348. doi: 10.1007/BF02978669

Ingwersen WW (2012) Life cycle assessment of fresh pineapple from Costa Rica. J Clean Prod 35:152-163. doi:10.1016/j.jclepro.2012.05.035

IPCC (2006) Chapter 11: N2O emissions from managed soils, and CO2 emissions from lime and urea application. In: Eggleston S, Buendia $\mathrm{L}$, Miwa $\mathrm{K}$ et al (eds) IPCC guidelines for national greenhouse gas inventories. Institute for Global Environmental Strategies, Hayama, Japan, pp 11.1-11.54

ISO 14040 (2006) Environmental management - Life cycle assessment Principles and framework. International Organization for Standardization, ISO 14040:2006

ISO 14044 (2006) Environmental management-life cycle assessmentrequirements and guidelines. International Standards Organization, 14044:2006 (E)

Lompo DJ-P (2012) Matter flows and balances in urban vegetable gardens of Bobo Dioulasso, Burkina Faso (West Africa). PhD thesis, University of Kassel
Lompo DJ-P, Sangaré SAK, Compaoré E et al (2012) Gaseous emissions of nitrogen and carbon from urban vegetable gardens in BoboDioulasso, Burkina Faso. J Plant Nutr Soil Sci 175:846-853. doi: 10.1002/jpln.201200012

Mila i Canals L, Muñoz I, Hospido A, et al. (2008) Life Cycle Assessment of domesctic vs. imported vegetables. Case studies on broccoli, salad crops and grean beans. Working paper $\mathrm{n}^{\circ} 01 /$ 08. Center for environmental strategy University of Surrey, Guilford, UK

Mouron P, Nemecek T, Scholz RW, Weber O (2006) Management influence on environmental impacts in an apple production system on Swiss fruit farms: combining life cycle assessment with statistical risk assessment. Agric Ecosyst Environ 114:311-322. doi:10.1016/ j.agee.2005.11.020

Nemecek T, Kägi T (2007) Life Cycle Inventories of Agricultural Production Systems. Final report ecoinvent $n^{\circ} 15$. Swiss Centre for Life Cycle Inventories Ecoinvent - ART, Zürich and Dübendorf, Switzerland

Predotova M, Gebauer J, Diogo RVC et al (2010) Emissions of ammonia, nitrous oxide and carbon dioxide from urban gardens in Niamey, Niger. F Crop Res 115:1-8. doi:10.1016/j.fcr.2009.09.010

Predotova M, Bischoff W-A, Buerkert A (2011) Mineral-nitrogen and phosphorus leaching from vegetable gardens in Niamey, Niger. J Plant Nutr Soil Sci 174:47-55. doi:10.1002/jpln.200900255

Rosendahl I, Laabs V, Atcha-Ahowe C et al (2009) Insecticide dissipation from soil and plant surfaces in tropical horticulture of southern Benin, West Africa. J Environ Monit 11:1157-1164. doi:10.1039/ b903470f

Sangare S, Compaore E, Buerkert A et al (2012) Field-scale analysis of water and nutrient use efficiency for vegetable production in a West African urban agricultural system. Nutr Cycl Agroecosyst 92:207224. doi:10.1007/s10705-012-9484-2

Sim S, Barry M, Clift R, Cowell SJ (2007) The relative importance of transport in determining an appropriate sustainability strategy for food sourcing. Int J Life Cycle Assess 12:422-431. doi:10.1065/ lca2006.07.259

Stehfest E, Bouwman L (2006) N2O and NO emission from agricultural fields and soils under natural vegetation: summarizing available measurement data and modeling of global annual emissions. Nutr Cycl Agroecosyst 74:207-228. doi:10.1007/s10705-006-9000-7

UN-HABITAT (2013) UN-Habitat Global Activities Report 2013. United Nations Human Settlements Programme, Available at www.unhabitat.org

Van Bol V, Claeys S, Debongnie P et al (2003) Pesticide indicators. Pestic Outlook 14:159. doi:10.1039/b308507b

Yadouleton AWM, Asidi A, Djouaka RF et al (2009) Development of vegetable farming: a cause of the emergence of insecticide resistance in populations of Anopheles gambiae in urban areas of Benin. Malar J 8:103. doi:10.1186/1475-2875-8-103 